Vol. 6, No. 1 Januari - Juni 2017

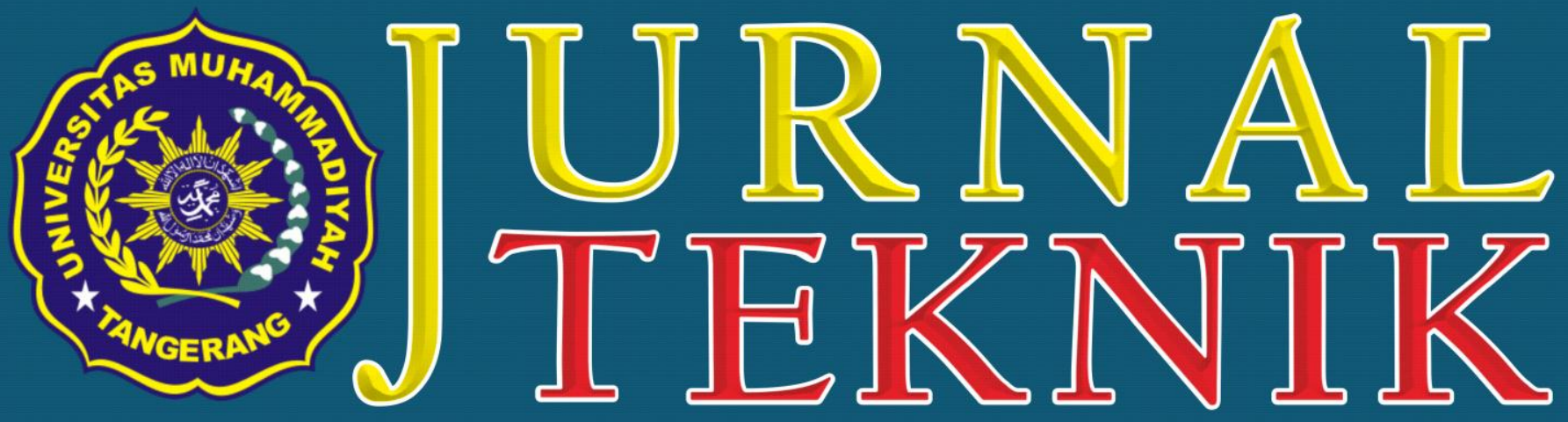

Alamat Redaksi: Jl. Perintis Kemerdekaan I No. 33, Cikokol Tangerang - TIp. (021) 51374916

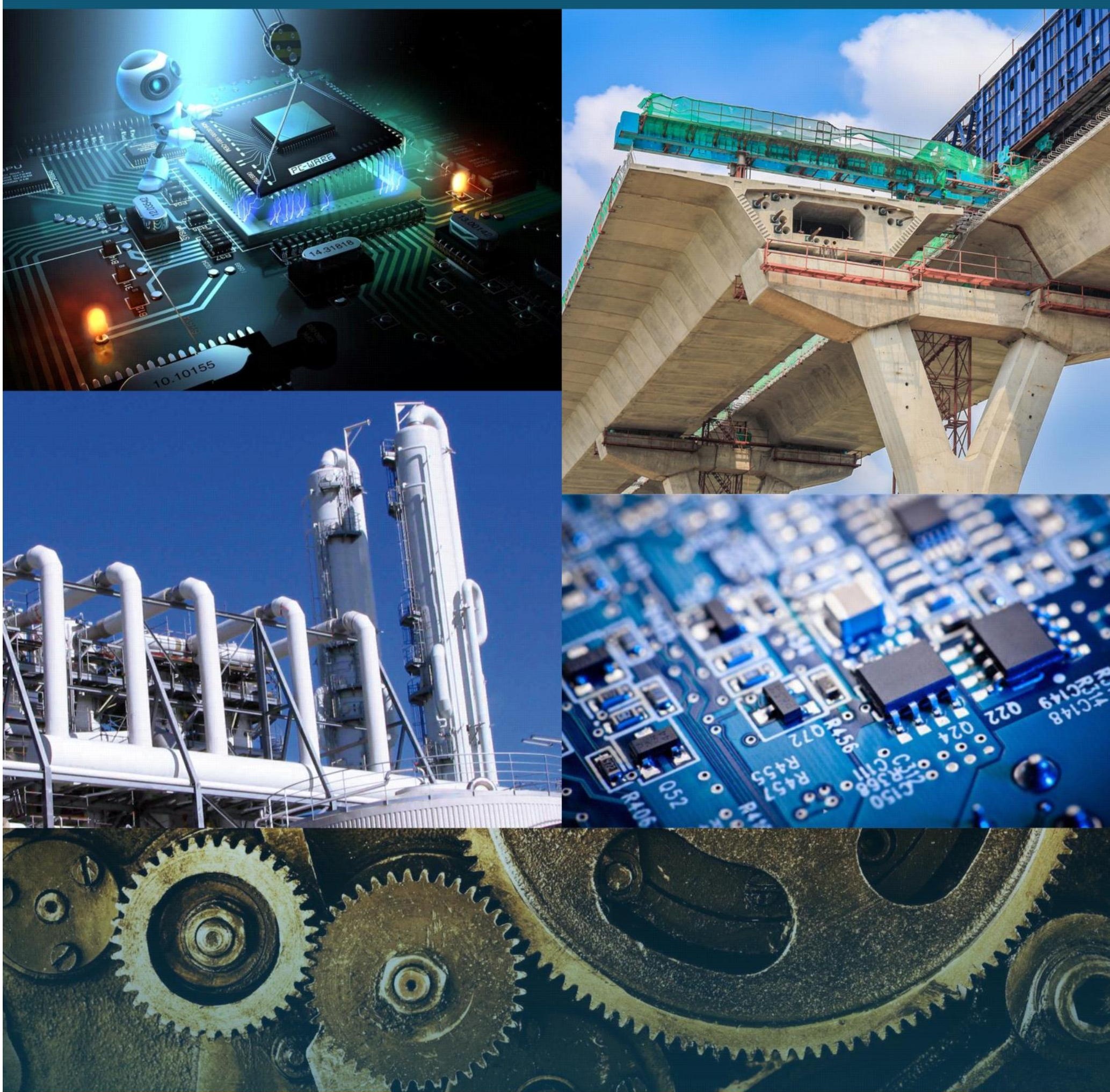




\section{J U R N A L TEKN I K}

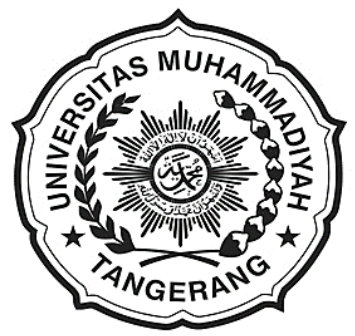

\section{UNIVERSITAS MUHAMMADIYAH TANGERANG}

Pelindung:

Dr. H. Achmad Badawi, S.Pd., SE., MM. (Rektor Universitas Muhammadiyah Tangerang)

Penanggung Jawab:

Ir. Saiful Haq, ST., M.Si.

(Dekan Fakultas Teknik)

Pembina Redaksi:

Rohmat Taufik, ST., M.Kom.

Drs. H. Syamsul Bahri, MSi.

Pimpinan Redaksi:

Ir. Sumardi Sadi, S.Pd., ST., MT.

Redaktur Pelaksana:

Yafid Efendi, ST, MT.

Editor Jurnal Teknik UMT:

Ir. Sumardi Sadi, S.Pd., ST., MT.

Dewan Redaksi:

Ir. Ali Rosyidin, ST., MM., MT.

Tri Widodo, ST.,MT.

Tina Herawati, ST., MT

Almufid, ST., MT.

Siti Abadiah, ST., MT.

M. Jonni, SKom., MKom.

Syepry Maulana Husain, S.Kom., M.Kom.

Ir. H. Bayu Purnomo, ST., MT

Kasubag:

Ferry Hermawan, MM.

Keuangan:

Elya Kumalasari, S.Ikom.

Setting \& Lay Out:

Muhlis, S.E

Saiful Alam, SE.

Mitra Bestari:

Prof. Dr. Aris Gumilar

Ir. Doddy Hermiyono, DEA

Dr. Ir. Budiyanto, MT.

Dr. Alimuddin, ST., MM., MT

J U R N A L T E K N I K

Diterbitkan Oleh:

Fakultas Teknik Universitas Muhammadiyah Tangerang

Alamat Redaksi:

Jl. Perintis Kemerdekaan I No. 33, Cikokol Tangerang Tlp. (021) 51374916

\begin{tabular}{|c|c|c|c|c|c|}
\hline \multirow{2}{*}{$\begin{array}{c}\text { Jurnal } \\
\text { Teknik }\end{array}$} & 6 & 1 & $1-97$ & $\begin{array}{c}\text { Jan'-Juni } \\
2017\end{array}$ & ISSN \\
\cline { 2 - 6 } & $2302-8734$ \\
\hline
\end{tabular}

\section{DAFTAR ISI}

1. PROSES PEMBUATAN ALAT PEMBUKA KALENG CAT DENGAN METODE CETAK PASIR (SAND CASTING) - 1-11 Ali Rosyidin

2. ANALISA DAN PERANCANGAN SISTEM KENDALI PLC XBC MINI BAS - 12-18 Alim Hardiansyah \& Bambang Suardi Waluyo

3. PENGATUR KESTABILAN SUHU PADA EGG INCUBATOR BERBASIS ARDUINO - 19-22

Abel Putra Hidayah \& Sumardi Sadi

4. METODE PEMBUATAN PONDASI BORE PILE DENGAN KINGPOST DAN METODE PONDASI DINDING PENAHAN TANAH DIAFRAGMA WALL - 23-29

Almufid

5. RANCANG BANGUN SIMULASI PENGENDALI LAMPU LALU LINTAS PADA PERSIMPANGAN DENGAN LIMA JALUR - 30-39

Rahma Farah Ningrum, Puji Catur Siswipraptini, \& Rosida N. Aziza

6. PERANCANGAN PROGRAM APLIKASI PENGENALAN WAJAH DENGAN MENERAPKAN METODE PRINCIPAL COMPONENT ANALYSIS DAN JARINGAN SYARAF TIRUAN - 40-49

M. Lutfi Aksani

7. KAJIAN PENERAPAN SI / TI DALAM MENINGKATKAN KUALITAS PEMBELAJARAN PADA TRAINING CENTER DENGAN MENGGUNAKAN METODOLOGI DeLone And McLean: STUDI KASUS PADA BINUS CENTER JAKARTA - 50-62 Nyoman Ayu Gita Gayatri \& GG Faniru Pakuning Desak

8. RANCANG BANGUN APLIKASI PEMBELAJARAN MATEMATIKA SD KELAS 6 BERBASIS ANDROID PADA SDN CIMONE 1 TANGERANG - 63-69

Winda Anggraeni \& Sri Mulyati

9. RANCANG BANGUN MESIN PERAJANG SINGKONG INDUSTRI RUMAHAN BERDAYA RENDAH - 70-76

Yafid Effendi \& Agus Danang Setiawan

10. RANCANG BANGUN TONGKAT ULTRASONIK UNTUK PENYANDANG TUNA NETRA BERBASIS ARDUINO UNO - 77-82

Bayu Purnomo \& Basuki Isnanto

11. ENTERPRISE RISK MANAGEMENT PADA CLOUD COMPUTING - 83-87

Samudera Dipa Legawa

12. ANALISIS NETWORK PLANNING DENGAN CRITICAL PATH METHOD (CPM) PADA PROYEK UNINTERATUBLE POWER SUPPLY (UPS) 80KVA PADA PT. HARMONI MITRA SUKSES (STUDI KASUS: RSAB HARAPAN KITA, JAKARTA) - 88-97

Hermanto, Novy Fauziah, \& Elfitria Wiratmani 


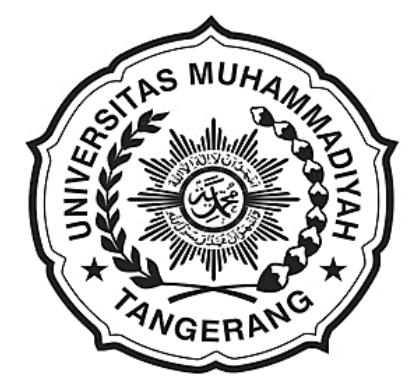

\section{Sambutan Dekan \\ Fakultas Teknik \\ Universitas Muhammadiyah Tangerang}

Puji Syukur kehadirat Allah Swt. karena berkat karunia dan ijin-Nyalah Tim penyusun Jurnal Teknik Fakultas Teknik Universitas Muhammadiyah Tangerang dapat menyelesaikan tugasnya tepat sesuai dengan waktu ditetapkan.

Saya menyambut baik diterbitkannya Jurnal Teknik Vol. 6 No. 1, Januari-Juni 2017, terbitnya jurnal ini, merupakan respon atas terbitnya Peraturan Menteri Pendidikan Nasional No. 17 Tahun 2010 tentang Pencegahan dan Penanggulangan Plagiat di Perguruan Tinggi; Surat Dirjen Dikti Nomor 2050/E/T/2011 tentang kebijakan unggah karya ilmiah dan jurnal; Surat Edaran Dirjen Dikti Nomor 152/E/T/2012 tertanggal 27 Januari 2012 perihal publikasi karya ilmiah yang antara lain menyebutkan untuk lulusan program sarjana terhitung mulai kelulusan setelah 2012 harus menghasilkan makalah yang terbit pada jurnal ilmiah.

Terbitnya Jurnal ini juga diharapkan dapat mendukung komitmen dalam menunjang peningkatan kemampuan para dosen dan mahasiswa dalam menyusun karya ilmiah yang dilandasi oleh kejujuran dan etika akademik. Perhatian sangat tinggi yang telah diberikan rektor Universitas Muhammadiyah Tangerang khususnya mengenai plagiarism dan cara menghindarinya, diharapkan mampu memacu semangat dan motivasi para pengelola jurnal, para dosen dan mahasiswa dalam menyusun karya ilmiah yang semakin berkualitas.

Saya mengucapkan banyak terimakasih kepada para penulis, para pembahas yang memungkinkan jurnal ini dapat diterbitkan, dengan harapan dapat dimanfaatkan seoptimal mungkin dalam peningkatan kualitas karya ilmiah.

Dekan Fakultas Teknik

Universitas Muhammadiyah Tangerang,

\section{Ir. Saiful Haq, M.Si.}




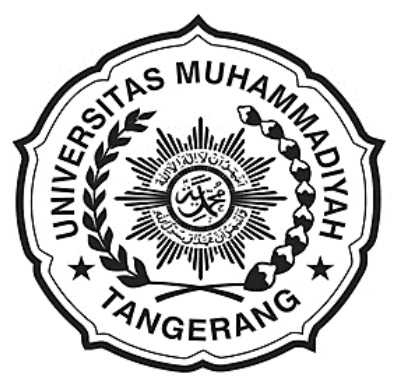

\section{Pengantar Redaksi}

Jurnal Teknik

Universitas Muhammadiyah Tangerang

Puji dan Syukur Alhamdulillah kami panjatkan kehadapan Allah Swt. atas karunia dan lindungan-Nya sehingga Jurnal Teknik Vol. 6 No. 1 edisi Januari-Juni 2017 dapat diterbitkan.

Menghasilkan karya ilmiah merupakan sebuah tuntutan perguruan tinggi di seluruh dunia. Tri Dharma Perguruan Tinggi yaitu darma pendidikan, darma penelitian, dan darma pengabdian kepada masyarakat mendorong lahirnya dinamika intelektual diantaranya menghasilkan karyakarya ilmiah. Penerbitan Jurnal Teknik ini dimaksudkan sebagai media dokumentasi dan informasi ilmiah yang sekiranya dapat membantu para dosen, staf dan mahasiswa dalam menginformasikan atau mempublikasikan hasil penelitian, opini, tulisan dan kajian ilmiah lainnya kepada berbagai komunitas ilmiah.

Buku Jurnal yang sedang Anda pegang ini menerbitkan 12 artikel yang mencakup bidang teknik sebagaimana yang tertulis dalam daftar isi dan terdokumentasi nama dan judul-judul artikel dengan jumlah halaman 1-97 halaman.

Jurnal Teknik ini tentu masih banyak kekurangan dan masih jauh dari harapan, namun demikian tim redaksi berusaha untuk ke depannya menjadi lebih baik dengan dukungan kontribusi dari semua pihak. Harapan Jurnal Teknik akan berkembang menjadi media komunikasi intelektual yang berkualitas, aktual dan faktual sesuai dengan dinamika di lingkungan Universitas Muhammadiyah Tangerang.

Tak lupa pada kesempatan ini kami mengundang pembaca untuk mengirimkan naskah ringkasan penelitiannya ke redaksi kami. Kami sangat berterimakasih kepada semua pihak yang telah membantu penerbitan Jurnal Teknik ini semoga buku yang sedang Anda baca ini dapat bermanfaat.

Pimpinan Redaksi Jurnal Teknik

Universitas Muhammadiyah Tangerang,

Ir. Sumardi Sadi, S.Pd., ST., MT. 


\title{
KAJIAN PENERAPAN SI / TI DALAM MENINGKATKAN KUALITAS PEMBELAJARAN PADA TRAINING CENTER DENGAN MENGGUNAKAN METODOLOGI DeLone And McLean: STUDI KASUS PADA BINUS CENTER JAKARTA
}

\author{
Nyoman Ayu Gita Gayatri ${ }^{1}$, GG Faniru Pakuning Desak ${ }^{2}$ \\ ${ }^{1}$ School of Computer Science, BINUS University \\ ${ }^{2}$ PJJ Sistem Informasi, BINUS University \\ Jln. K.H Syahdan No. 9, Palmerah, Jakarta Barat 11480 \\ E-mail: ${ }^{1}$ nyoman.gita@gmail.com ; ${ }^{2}$ gg.faniru@gmail.com
}

\begin{abstract}
The development of information technology has given the world an influence on education, especially in learning. The role of information technology and information systems in the field of informal education and one of them can be seen in the use of instructional media in the learning space, the utilization of classrooms and academic information system that can facilitate the conduct implementation of academic activities. Binus Center Jakarta is one of the providers of informal education, especially education. Binus Center using information technology in improving quality of learning, there are three things that must be realized that (1) Participants and the instructor must have access to digital technology and the Internet in classrooms (2) Available materials quality and meaningful, and (3) Instructors must have knowledge and skills in using the tools and digital resources to help participants to achieve quality learning. This study aimed to see whether the implementation of information systems/information technology (IS / IT) affects the quality of learning in non-formal education, using case studies on Jakarta Binus Center Special Class program in particular. This study uses qualitative research methodology with inferential statistical analysis to describe correlation of information systems implementation to quality learning.
\end{abstract}

Keywords: Implementation of IT / SI, Quality Learning.

1. PENDAHULUAN DAN KERANGKA PEMIKIRAN

\subsection{Latar Belakang}

Investasi Sistem dan Teknologi Informasi sudah menjadi hal yang wajib dilakukan oleh hampir semua kegiatan bisnis atau usaha termasuk dunia pendidikan. Besarnya total investasi untuk Sistem dan Teknologi Informasi menjadi tantangan baru bagi pihak pengelola untuk melakukan evaluasi terhadap kontribusi yang diberikan oleh Sistem Insformasi (SI) dan Teknologi Informasi (TI).

Training Center menitik beratkan semua kegiatan mereka untuk peningkatkan mutu pendidikan supaya menjadi Training Center yang terdepan dalam menghasilkan lulusan. Keberhasilan Training Center adalah dilihat dari lulusan yang dapat bersaing di dunia industri atau dunis usaha yang akan digeluti para lulusannya dikemudian hari.
Pihak pengelola Training Center akan memenuhi semua sarana dan prasarana yang mendukung proses belajar termasuk memanfaatkan implementasi SI/TI untuk meningkatkan kualitas pembelajaran.

Pengkajian atau evaluasi penerapan SI/TI perlu dilakukan untuk mengetahui apakah SI/TI yang ada sudah berdungsi sesuai dengan sasaran. Dari evaluasi yang telah dilakukan, maka pengelola akan melakukan kualifikasi kontribusi masing-masing komponen SI/TI. Kualifikasi kontribusi masing-masing komponen SI/TI ini akan dapat digunakan oleh pihak pengelola untuk membuat sebuah solusi terhadap investasi SI/TI apakah berhenti memanfaatkan Si/TI, memperbaiki SI/TI yang ada atau mengganti SI/TI yang digunakan saat ini. 


\subsection{Masalah Penelitian}

a. Identifikasi Masalah

Organisasi pendidikan seperti Training

Center dipastikan sudah menginvestasikan banyak dana untuk SI/TI. Banyaknya investasi kebutuhan SI/TI ini mendorong pihak pengelola ingin melihat dan mengetahui seberapa besar dampak penerapan SI/TI di organisasi mereka. Hal ini perlu dilakukan terutama untuk meningkatkan utilitas SI/TI yang sudah ada untuk dapat berkompetensi mendapat pasar. Setelah melihat kontribusi komponen SI/TI, pihak pengelola akan dapat memutuskan untuk berinvenstasi SI/TI yang hanya menguntungkan, sehingga akan bisa mengurangi total investasi.

Berdasarkan uraian diatas, maka permasalahan yang akan dibahas pada penelitian ini adalah apakah implementasi teknologi dan sistem informasi dapat mempengaruhi kualitas pembelajaran di Training Center.

\section{b. Batasan Masalah}

Adapun batasan masalah pada penelitian ini adalah:

1. Penelitian ini dilakukan di Binus Center Jakarta khususnya program Special Class;

2. Penelitian ini dibatasi pada SI/TI yang telah diimplementasikan untuk membantu peningkatan kualitas pembelajaran, akan tetapi tidak termasuk di dalamnya rencana implementasi SI/TI berikutnya;

3. Pengamatan trend kualitas peserta perprogram jurusan berdasarkan distribusi indeks prestasi perangkatan; dan

4. Evaluasi kinerja akademik dari segi kualitas lulusan.

\section{c. Rumusan Masalah}

Dari hasil identifikasi masalah di atas dan batasan-batasan yang telah ditetapkan diatas, penulis merumuskan masalah utama dalam penelitian ini yaitu:

1. Apakah penerapan SI/TI berpengaruh terhadap kualitas pembelajaran di Training Center?

2. Faktor apakah yang mempengaruhi tingkat kualitas pembelajaran di Training Center?
3. Bagaimana rekomendasi penerapan SI/TI di Training Center dapat berpengaruh dengan kualitas pembelajaran?

\subsection{Tujuan dan Manfaat}

a. Tujuan Penelitian

Adapun tujuan dalam penelitian ini yaitu:

1. mengkaji dan mengevaluasi apakah implementasi SI/TI dapat meningkatkan kualitas pembelajaran di Training Center.

2. Mengukur kualitas lulusan peserta di Training Center berdasarkan penerapan SI/TI.

\section{b. Manfaat Penelitian}

1. Memperoleh gambaran penerapan SI/TI di dunia pendidikan khususnya pada Training Center.

2. Sebagai masukan terhadap pengelola dunia pendidikan untuk dapat berinvestasi SI/TI untuk dapat digunakan seefektif dan seefisien mungkin.

3. Untuk memperbanyak penelitian penggunaan SI/TI, sehingga penggunaan SI/TI bisa lebih optimal.

4. Untuk bahan pembanding bagi peneliti SI/TI yang lain.

\section{LANDASANPEMIKIRAN}

\subsection{Teknologi Informasi}

Sebelum membahas mengenai pengertian dari teknologi informasi, kita lihat terlebih dahulu tentang pengertian informasi dan pengertian teknologi menurut para ahli. Informasi adalah data yang telah diproses menjadi bentuk yang memiliki arti bagi penerima dan dapat berupa fakta, suatu nilai yang bermanfaat. Jadi ada suatu proses transformasi data menjadi suatu informasi. Secara umum informasi dapat diartikan sebagai data yang telah diproses menjadi suatu bentuk yang mempunyai arti dan berguna bagi manusia. Dengan kata lain, informasi adalah data berguna yang dapat diolah menjadi informasi sehingga dapat dijadikan dasar untuk mengambil keputusan yang tepat [Gundar 2005].

\subsection{Sistem Informasi}

Sistem informasi merupakan kombinasi dari orang-orang, hardware, software, ja- 
ringan komunikasi dan sumber daya data yang mengumpulkan, mengubah, dan menyebutkan informasi dalam sebuah organisasi [O’Brien 2006,6].

\subsection{Pemanfaatan Sistem Informasi}

Pemanfaatan sistem informasi untuk menjalankan bisnis sudah menjadi keharusan dihampir semua organisasi.Pada perusahaan dengan jumlah investasi SI/TI yang signifikan mengharuskan pihak pengelola harus mampu mengoptimalkan peran SI/TI untuk mendukung pertumbuhan bisnis itu sendiri. Pihak pengelola juga harus mampu mendefinisikan SI/TI supaya dapat mengantisipasi resiko yang mungkin muncul, mengurangi biaya dan juga memikirkan regulasi dan license dari vendor software yang akan digunakan.

\subsection{DeLone and McLean Model}

Dalam rangka memberikan definisi umum dan komprehensif IS keberhasilan yang mencakup perspektif yang berbeda dari sistem informasi mengevaluasi, DeLone dan McLean meninjau definisi yang ada IS keberhasilan dan langkah-langkah yang sesuai mereka, dan diklasifikasikan ke dalam enam kategori utama. Jadi, mereka menciptakan suatu model pengukuran multidimensi dengan ketergantungan antara keberhasilan kategori yang berbeda. Model DeLone and McLean dapat dilihat pada Gambar 1[DeLone \& McLean 2003].

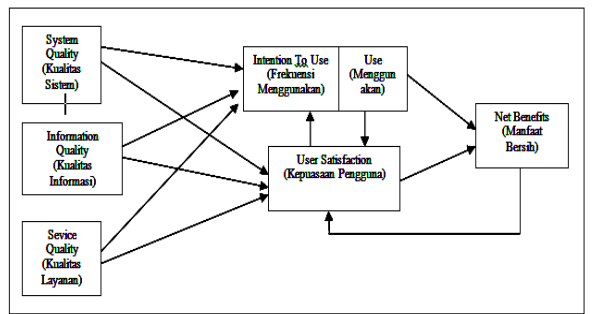

Gambar 1. D \& M Model Kesuksesan Sistem Informasi [DeLone\&McLean 2003]

\subsection{Kualitas Informasi (Information Quality) \\ Information Quality mempunyai hu-} bungan yang sangat signifikan dengan tingkat satisfaction pengguna. Kriteria Information Quality yang diukur adalah akurasi informasi (accuracy), informasinya benar (timeliness), relefan (relevance), bisa dimengerti (understandability), lengkap (completeness) dan aman (security) [DeLone \& McLean 2003].

\subsection{Kulitas Pelayanan (Service Quality)}

Service Quality sangat berpengaruh besar pada tingkat satisfaction pelanggan atau pengguna. Kriteria yang digunakan sebagai alat ukur service quality diantaranya adalah kecepatan memperbaiki kesalahan (error recovery), tanggung jawab (responsibilities), ketersediaan manual dan technical support [Delone\&McLean 2003].

\subsection{Penggunaan Informasi (System Use) dan Kepuasan Pengguna (User Satisfaction) \\ D \& M IS Success Model mengatakan} pengguna SI/IT efektif dan berhasil bila system itu digunakan dan informasi yang dihasilkan sesuai yang diinginkan oleh pengguna. Kriteria yang digunakan untuk mengukur keberhasilan SI/TI dari dimensi System Use adalah seringnya digunakan (frequently of use), waktu penggunaan (usage pattern) dan tingkat ketergantungan (dependency). Selain informasi yang dihasilkan sesuai yang diinginkan pengguna, user satisfaction juga diukur berdasarkan kriteria seperti kenyamanan menggunakan system, keinginan untuk membeli sistem yang sama dan promosi ke pengguna lain [DeLone \& McLean 2003].

\subsection{Manfaat Bersih (Net Benefits)}

Net benefits menjadi ukuran terakhir keberhasilan pemanfaat SI/TI pada D \& M IS Success Model. Net Benefits merupakan pengaruh langsung terhadap individu pengguna (Individual Impact) dan juga kepada kelompok atau organisasi (Organizational Impact).

\subsection{Kualitas Pembelajaran (Learning Quality)}

Learning Quality adalah kualitas dapat dimaknai dengan istilah mutu atau juga keefektifan. Secara definitif efektivitas dapat dinyatakan sebagai tingkat keberhasilan dalam mencapai tujuan atau sasarannya. Efektivitas ini sesunguhnya merupakan suatu konsep yang lebih luas mencakup berbagai faktor di dalam maupun di luar diri seseorang. Dengan demikian efektivitas tidak hanya dapat dilihat dari sisi produktivitas, akan tetapi juga dapat pula dilihat dari sisi persepsi atau sikap orangnya. Di samping 
itu, efektivitas juga dapat dilihat dari bagaimana tingkat kepuasan yang dicapai oleh orang.

\subsection{Aplikasi Teknologi Dalam Metodologi Pembelajaran}

Peningkatan kualitas pembelajaran dapat dilakukan dengan menggunakan pendekatan Teknologi Pendidikan, yaitu dengan cara mencari dan mengidentifikasi permasalahan yang dihadapi dalam pembelajaran kemudian dicarikan pemecahannya melalui aplikasi teknologi pendidikan. Upaya pemecahan permasalahan pendidikan terutama masalah kualitas pembelajaran, dapat ditempuh dengan cara penggunaan berbagai sumber belajar dan penggunaan media pembelajaran yang berfungsi sebagai alat bantu dan meningkatkan kadar hasil belajar peserta [Kasidi 2000].

\subsection{AMOS}

AMOS (Analysis Of Moment Structure) merupakan salah satu program atau software yang digunakan untuk mengistemasi model pada model persamaan structural (SEM) ([Ghozali, 2008]).AMOS digunakan sebagai pendekatan umum analisis data dalam Model Persamaan Struktural (Structural Equation Model) atau yang dikenal dengan SEM. SEM dikenal juga sebagai Analysis of Covariance Structures atau disebut juga model sebab akibat (causal modeling) Dengan menggunakan Amos maka perhitungan rumit dalam SEM akan jauh lebih mudah dilakukan dibandingkan dengan menggunakan perangkat lunak lainnya. Lebih lagi penggunaan Amos akan mempercepat dalam membuat spesifikasi, melihat serta melakukan modifikasi model secara grafik dengan menggunakan tool yang sederhana.

\subsection{Tinjauan Studi}

Peneliti Begona Perez dan Mira pada penelitian ini berdasarkan taksonomi Mason, DeLone dan McLean mengusulkan enam kategori yang berbeda atau dimensi IS keberhasilan: system quality, information quality, penggunaan, satisfaction pengguna, dampak individu, dan dampak organisasi. DeLone dan McLean mengkategorikan setiap studi dan langkah-langkah menjadi satu dari enam kategori yang dikembangkan untuk taksonomi. Pada penelitian ini memberikan dukungan untuk menggunakan Model DeLone dan McLean IS Sukses untuk menjelaskan variasi pada tingkat analisis organisasi di lingkungan $e$ commerce. Hasil dari model ini memberikan dukungan yang signifikan untuk hubungan antara service quality, system quality, and use; use and satisfaction; and use and net benefits

Peneliti Radityo dan zulaikhapada Penelitian ini bertujuan mengevaluasi apakah sistem informasi manajemen yang dikembangkan dalam sebuah institusi (dalam penelitian ini sistem informasi yang dikembangkan diberi sebutan SIMAWEB). Pada penelitian ini Model kesuksesan sistem informasi DeLone and Mc Lean's Model tidak sepenuhnya terbukti secara empiris dalam kasus pengembangan Sistem informasi Manajemen berbasis Web (SIMAWEB) di Fakultas Ekonomi Undip.

Penelitian yang dilakukan oleh Juhani Iivari ([Iivari 2002]) yang berjudul " $A n$ Empirical Test of the DeLone-McLean Model of Information System Success". Studi ini melakukan uji empiris toeri model keberhasilan IS DeLone dan McLean (1992) sebagai prediksi model. Secara keseluruhan temuan ini didukung tetapi ada banyak ambiguitas terkait dengan model DeloneMcLean sebagai model. Penguatan teori yang mendasari model Delone-McLean akan membutuhkan perhatian lebih, temuan ini menunjukkan bahwa model Delone-McLean dapat diterapkan untuk mengukur keberhasilan sebuah system informasi.

\subsection{Tinjauan Objek Penelitian}

Binus Center adalah salah satu lembaga pelatihan komputer yang membuka kesempatan kepada semua orang untuk melakukan kerjasama berupa franchise dengan membuka outlet baru. Penelitian ini akan mencoba meneliti pemanfaatan teknologi informasi di Binus Center yang berada di Jakarta. Mutu pelatihan di Binus Center ditentukan oleh dua aspek yang sangat penting yaitu kurikulum dan tenaga pengajar. Seluruh kurikulum di Binus Center melalalui tahap riset dan pengolah ilmu pengetahuan oleh tim khusus yaitu $R \& D$ division. 
Pengajar di Binus Center disebut sebagai instruktur.Seluruh instruktur ditingkatkan kemampuannya secara instensif melalui pelatihan, evaluasi dan sertifikasi sebagai BCI (Binus Certified Instructor).

Model delone dan mclean menyatakan bahwa kualitas sistem,kualitas informasi kualitas pelayanan baik sendiri atau bersama-sama mempengaruhi penggunaan dan kepuasan pengguna. Pada umumnya, besarnya tingkat pengaruh penggunaan sistem akan mempengaruhi kepuasan pengguna secara positif atau negatif,dan tingkat kepuasan pengguna juga mempengaruhi penggunaan. Penggunaan dan kepuasan pengguna mempengaruhi langsung manfaatmanfaat bersih sehingga dalam model ini dapat dibuat suatu pengaruh antar variabel sebagai berikut:

1. Kualitas sistem memiliki pengaruh terhadap penggunaan dan kepuasan pengguna.

2. Kualitas informasi memilki pengaruh terhadap penggunaan dan kepuasan pengguna.

3. Kualitas pelayanan memilki pengaruh terhadap penggunaan dan kepuasan.

4. Penggunaan memiliki pengaruh terhadap kepuasan pengguna dan net benefit.

5. Kepuasan pengguna memilki pengaruh terhadap penggunaan net benefit.

Kualitas sistem mengukur baik atau buruknya sistem, konsisten tampilan pengguna, kemudahaan penggunaan tingkat respon sistem interaktif, dokumentasi, dan kualitas. Kualitas informasi mengukur, aktualitas, akurasi, hubungan, dan bentuk informasi yang dihasilkan sistem informasi. Penggunaan mengukur penggunaan sistem informasi pada umumnya, penggunaan sistem informasi dalam lingkup pekerjaan, dan banyaknya paket informasi yang digunakan dalam pekerjaan. Kepuasan pengguna mengukur kesuksesan interaksi antara sistem informasi dengan penggunaanya. Manfaat-manfaat bersih mengukur pengaruh sistem informasi terhadap kinerja penggunanya,dalam empat aspek yaitu produktivitas, inovasi, kepuasan pelanggan, dan pengendalian manajemen.

Penulis mencoba membuat penelitian dengan melakukan modifikasi terhadap model yang dibuat oleh DeLone \& McLean adalah keberhasilan penggunaan e-commerce, sedangkan pada penelitian ini Net Benefits yang akan dicoba dilihat adalah keberhasilan Learnning Quality.

Model penelitian hasil modifikasi yang penulis buat akan seperti dibawah ini:

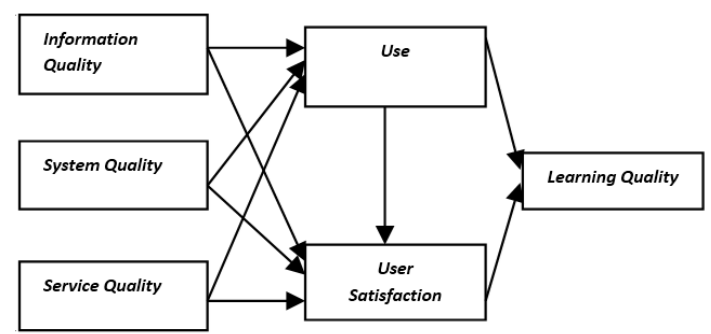

Gambar 2 Kerangka Konsep Pengaruh Antar Variabel

Sedangkan indikator yang digunakan untuk mengukur masing-masing variabel laten dapat dilihat pada tabel dibawah ini:

Tabel 1. Indikator Variabel

\begin{tabular}{|c|c|c|c|}
\hline No. & $\begin{array}{c}\text { Variable } \\
\text { Laten }\end{array}$ & Indikator & Referensi \\
\hline 1. & Service Quality & $\begin{array}{ll}\text { - Assurance } \\
- \text { Empathy } \\
\text { - Responsiveness }\end{array}$ & $\begin{array}{l}\text { [Delone\&McLean } \\
\text { 2003] }\end{array}$ \\
\hline 2 & System Quality & $\begin{array}{ll}\text { - Ease of use } \\
\text { - System flexibility } \\
\text { - Response time } \\
\text { - Reability }\end{array}$ & $\begin{array}{l}\text { Hamilton dan } \\
\text { Chervany 1981 dalam } \\
\text { [Radzul 2007] }\end{array}$ \\
\hline 3 & $\begin{array}{l}\text { Information } \\
\text { Quality }\end{array}$ & $\begin{array}{ll}\text { Accuracy } \\
- \text { Timeliness } \\
- \text { Completeness } \\
- \text { Format }\end{array}$ & $\begin{array}{l}\text { Pitt dan Watson } 1997 \\
\text { dalam [Radzul 2007] }\end{array}$ \\
\hline 4 & $\begin{array}{l}\text { Learning } \\
\text { Quality }\end{array}$ & $\begin{array}{ll} & \text { Effort regulation } \\
\text { Self efficacy for } \\
\text { learning and } \\
\text { performance } \\
\text { Control-of- } \\
\text { learning beliefs } \\
\text { Time and study } \\
\text { environment } \\
\text { management }\end{array}$ & [Valle et al. 2009] \\
\hline 5 & $\begin{array}{l}\text { User } \\
\text { Satisfaction }\end{array}$ & $\begin{array}{ll} & \text { Dependency } \\
\text { - } & \text { Comportability } \\
\text { - Respon Time } \\
\text { - Online Help }\end{array}$ & $\begin{array}{l}\text { McGill et al. } 2003 \\
\text { dalam [Radzul 2007] }\end{array}$ \\
\hline 6 & Use & $\begin{array}{l}\text { Frequency of use } \\
\text { Time of use }\end{array}$ & [Livari 2002] \\
\hline
\end{tabular}

\subsection{Hipotesis Penelitian}

Diduga implementasi SI/TI berpengaruh terhadap Learning Quality.

\section{DESAIN PENELITIAN}

\subsection{Metode Penelitian}

Metode penelitian yang akan dilakukan pada penelitian kali ini adalah penelitian kuantitatif dan termasuk dalam kategori penelitian explanatory, yaitu penelitian yang berisi pembuktian yang dibangun melalui teori dengan pendekatan model kesuksesan sistem informasi delone dan mclean (2003). Setelah diuji menggunakan salah satu 
perangkat lunak dalam hal ini AMOS.

a. Metode Pemilihan Sampel

Populasi pada penelitian kali ini diambil dari peserta, instruktur, dan juga staff yang menggunakan SI/TI yang sudah diimplementasikan di Binus Center.

Sampel merupakan bagian dari populasi. Metode pemilihan sampel yang digunakan adalah metode non-probability sampling dengan tipe purposive sampling yaitu teknik pengambilan sampel secara tidak acak akan tetapi didasarkan pada sifat atau kriteria-kriteria tertentu sesuai dengan yang ditetapkan oleh peneliti. Pada penelitian ini yang dapat menjadi responden adalah staff, peserta pelatihan, dan instruktur yang menggunakan penerapan SI/TI yang ada di Binus Center.

\section{b. Ukuran Sampel}

Pada pemodelan SEM dibutuhkan ukuran sample sebesar minimum 100 atau menggunakan perbandingan lima observasi untuk setiap parameter yang diestimasi, artinya jika dalam pengembangan model melibatkan 20 parameter, maka sampel minimal yang harus digunakan adalah sebanyak 100 responden. Dalam penelitian ini menggunakan 100 sampel yang didapat dari 100 responden mengisi kuesioner yang disebarkan kepada peserta, instruktur, dan staff.

\section{c. Metode Pengumpulan Data}

Teknik atau metode pengumpulan data merupakan cara-cara yang diperlukan untuk memperoleh data di lapangan, yaitu satu teknik dalam melakukan penelitian yang dilakukan secara langsung terhadap objek penelitian. Pada penelitian ini teknik pengumpulan data dilakukan dengan bantuan kuesioner.

\section{d. Instrumentasi}

Instrumen untuk mengumpulkan data dari responden yang digunakan adalah kuesioner. Pertanyaan didesain supaya dapat dijawab dengan cepat oleh responden sehingga diharapkan pengembalian kuesioner yang dibagi dapat mencapai 95\%.Jawaban responden berbentuk Semantic Differential Scale, yaitu mencentang nilai 1 (Strongly Disagree) sampai nilai 7 (Strongly Agree).
Kuesioner yang dibagikan terdiri dari 22 pertanyaan yang dikelompokan menjadi 6 bagian sebagai berikut (indikator - indikator masing - masing pertanyaan disesuaikan dengan indikator pada Tabel 3.1:

1. Pertanyaan 1 sampai 4 akan digunakan untuk mengukur Learning Quality;

2. Pertanyaan 5 sampai 9 akan digunakan untuk mengukur System Quality;

3. Pertanyaan 10 sampai 13 akan digunakan untuk mengukur Information Quality;

4. Pertanyaan 14 sampai 16 akan digunakan untuk mengukur Service Quality;

5. Pertanyaan 17 sampai 20 akan digunakan untuk mengukur User Satisfaction; dan

6. Pertanyaan 21 sampai 22 akan digunakan untuk mengukur Use.

\subsection{Indentifikasi Variabel Penelitian}

Penelitian ini terdiri dari variabel dependen (bergantung) dan variabel independen (bebas). Pada analisa regresi akan melihat atau memprediksi seberapa besar pengaruh satu atau beberapa variabel bebas terhadap variabel bergantung (dependen). Variabel-variabel yang digunakan pada penelitian ini adalah sebagai berikut:

\section{a. Variabel Dependen}

Variabel dependen yaitu variabel yang dipengaruhi oleh variabel yang lain. Pada penelitian ini, variabel-variabel dependen adalah sebagai berikut:

- $\quad$ Learning Quality $(L Q)$

- User Satisfaction (US)

- Use (U)

\section{b. Variabel Independen}

Variabel Independen adalah variable yang mempengaruhi variabel dependen. Pada penelitian ini, variabel-variabel independen adalah sebagai berikut:

- Information Quality (IQ)

- Service Quality $(\operatorname{SrQ})$

- System Quality $(S Q)$

\subsection{Analisis Statistik Deskriptif}

Tujuan analisis ini memberikan gambaran atau detesis suatu data berupa ratarata, standar deviasi, variance, maksimum, minimum, kutosis (puncak dari distribusi data), dan skewness (kemencengan distribusi data). 


\subsection{Metode Olah Data Dengan Structural Equation Model (SEM)}

a. Pengembangan model berbasis teori

Tujuan pengembangan model berbasis teori ini adalah untuk mengembangkan sebuah model yang mempunyai justifikasi (pembenaran)secara teoritis yang kuat, untuk mendukung upaya analisi terhadap suatu masalah yang menjadi obyek peneliti.

\section{b. Membangun diagram jalur (path diagram)}

Tujuan pembuatan path diagram adalah untuk memudahkan peneliti dalam melihat hubungan kausalitas yang diuji hubungan antar konstruk ditunjukan oleh anak panah. Anak panah yang mengarah dari konstruk satu ke konstruk lainnya menunjukan hubungan kausalitas.Pada peelitian ini, diagram jalur adalah seperti Gambar 3 berikut ini.

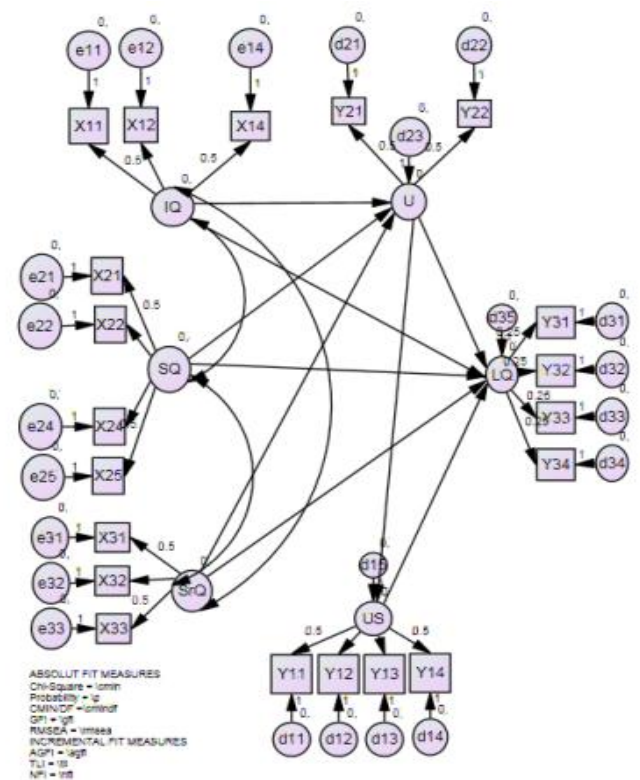

Gambar 3 Diagram Jalur

\section{c. Konversi Diagram Alur Ke Dalam Persamaan Structural}

Tujuan tahapan ini adalah merumuskan persamaan structural berdasarkan diagram jalur yang dibangun pada langkah sebelumnya. Persamaan structural akan dibangun dengan pedoman berikut:

Indikator $=\lambda$ Konstruk + Error

$X=\lambda$ Variabel Laten Eksogen + Error

$Y=\lambda$ Variabel Laten Endogen + Error
Pada penelitian ini, bentuk persamaan konstruk eksogen dan endogen adalah sebagai berikut:

\section{US = 9,57 + 0,478 SQ}

Pada penelitian ini, pengukuran indikator eksogen dan endogen adalah sebagai berikut:

Konstruk Eksogen: Information Quality (= IQ)

1. $\mathrm{X} 11=\lambda 11 \mathrm{IQ}+\mathrm{e} 11$

2. $\mathrm{X} 12=\lambda 12 \mathrm{IQ}+\mathrm{e} 12$

3. $\mathrm{X} 13=\lambda 13 \mathrm{IQ}+\mathrm{e} 13$

4. $\mathrm{X} 14=\lambda 14 \mathrm{IQ}+\mathrm{e} 14$

Konstruk Eksogen: Service Quality $(=S Q)$

5. $\mathrm{X} 21=\lambda 21 \mathrm{SQ}+\mathrm{e} 21$

6. $\mathrm{X} 22=\lambda 22 \mathrm{SQ}+\mathrm{e} 22$

7. $\mathrm{X} 23=\lambda 23 \mathrm{SQ}+\mathrm{e} 23$

8. $\mathrm{X} 24=\lambda 24 \mathrm{SQ}+\mathrm{e} 24$

9. $\mathrm{X} 25=\lambda 25 \mathrm{SQ}+\mathrm{e} 25$

Konstruk Eksogen: Service Quality $(=\operatorname{SrQ})$

10. $\mathrm{X} 31=\lambda 31 \mathrm{SrQ}+\mathrm{e} 31$

11. $\mathrm{X} 32=\lambda 32 \mathrm{SrQ}+\mathrm{e} 32$

12. $\mathrm{X} 33=\lambda 33 \mathrm{SrQ}+\mathrm{e} 33$

Konstruk Endogen: User Satisfaction (= US)

13. $\mathrm{Y} 11=\lambda 11 \mathrm{US}+\mathrm{d} 11$

14. $\mathrm{Y} 12=\lambda 12 \mathrm{US}+\mathrm{d} 12$

15. $\mathrm{Y} 13=\lambda 13 \mathrm{US}+\mathrm{d} 13$

16. $\mathrm{Y} 14=\lambda 14 \mathrm{US}+\mathrm{d} 14$

Konstruk Endogen: Use $(=U)$

17. $\mathrm{Y} 21=\lambda 21 \mathrm{U}+\mathrm{d} 21$

18. $\mathrm{Y} 22=\lambda 22 \mathrm{U}+\mathrm{d} 22$

Konstruk Endogen: Learning Quality $(=L Q)$

19. $\mathrm{Y} 31=\lambda 31 \mathrm{LQ}+\mathrm{d} 31$

20. $\mathrm{Y} 32=\lambda 32 \mathrm{LQ}+\mathrm{d} 32$

21. $\mathrm{Y} 33=\lambda 33 \mathrm{LQ}+\mathrm{d} 33$

22. $\mathrm{Y} 34=\lambda 34 \mathrm{LQ}+\mathrm{d} 34$

\subsection{Pengelompokan Data}

a. Data Profile Responden

Jumlah responden pada penelitian ini adalah sebanyak 100 responden. Dalam penyebaran kuesioner, peneliti menyebar langsung terhadap responden dan meng-gunakan email. Email digunakan untuk me-nyebarkan kuis ke Binus Center Kelapa Gading, Binus Center Raden Saleh, Binus Center Bintaro. 
Tabel 2 Profil Responden Penelitian

\begin{tabular}{|c|c|c|}
\hline Klasifikasi Responden & Jumlah & Presentasi \\
\hline Jenis Responden : & & \\
\hline$-\quad$ Staff & 8 & $8 \%$ \\
\hline Peserta & 67 & $67 \%$ \\
\hline Instruktur & 25 & $25 \%$ \\
\hline Jumlah & 100 & $100 \%$ \\
\hline Jenis Kelamin : & & \\
\hline - Pria & 53 & $53 \%$ \\
\hline - Wanita & 47 & $47 \%$ \\
\hline Jumlah & 100 & $100 \%$ \\
\hline \multicolumn{3}{|l|}{ Jenjang Pendidikan : } \\
\hline - SMA & 8 & $8 \%$ \\
\hline - $\quad$ D3 & 25 & $25 \%$ \\
\hline$-\quad \mathrm{S} 1$ & 55 & $55 \%$ \\
\hline \multirow[t]{2}{*}{$-\quad \mathrm{S} 2$} & 12 & $12 \%$ \\
\hline & 100 & $100 \%$ \\
\hline
\end{tabular}

Keseluruhan responden yang diperoleh oleh penelitian adalah peserta, staff, dan instruktur di Binus Center Jakarta yang menggunakan SI/TI. Dilihat dari profil responden penelitian ini, kebanyakan diantaranya adalah peserta $(67 \%)$, berjenjang studi S1 (55\%).

Kebanyakan responden merupakan mahasiswa, sedangkan pekerja terbilang sedikit. Hal ini disebabkan mahasiswa merupakan komunitas yang paling banyak dan mudah ditemui di Training Center. Berdasarkan profil responden, jumlah responden yang berjenis kelamin laki-laki tidak berbeda jauh dengan jumlah responden yang berjenis kelamin perempuan. Hal ini masuk akal, karena pada zaman yang serba modern seperti sekarang ini, gender atau jenis kelamin tidak dianggap sebagai pembeda dalam meraih pendidikan di Training Center.

\section{HASIL PENELITIAN}

\subsection{Analisis Statistik Deskriptif}

Analisa ini digunakan untuk memberikan penjelasan tentang jawaban responden. Dengan analisa ini dapat diketahui nilai range, minimum, maksimum, rata-rata (mean), standart deviasi, variance, skewness dan kurtosis. Data analisa deskriptif ini dapat dilihat pada lampiran

Analisa ini digunakan untuk memberikan penjelasan tentang jawaban responden. Dengan analisa ini dapat diketahui nilai range, minimum, maksimum, rata-rata (mean), standart deviasi, variance, skewness dan kurtosis. Data analisa deskriptif ini dapat dilihat pada lampiran.

\subsection{Ukuran Sampel}

Ukuran sampel yang harus di penuhi dalam pemodelan SEM, minimum berjumlah 100 penelitian ini menggunakan sampel sebanyak 100, oleh karena itu jumlah sampel tersebut telah memenuhi persyaratan ukuran sampel.

\subsection{Uji normalitas}

Distribusi data dikatakan normal jika angka cr skwenwss atau angka cr kurtosis ada diantara $-2,58$ sampai 2,58 pada tabel Assesment of normality yang di sajikan pada table Assesment of normality yang terdapat pada table 4.2 di lihat secara multivariate nilai c.r yaitu -0.297 yang nilainya di bawah -2.58 . Sehingga dapat di simpulkan bahwa data berdistribusi tidak normal.

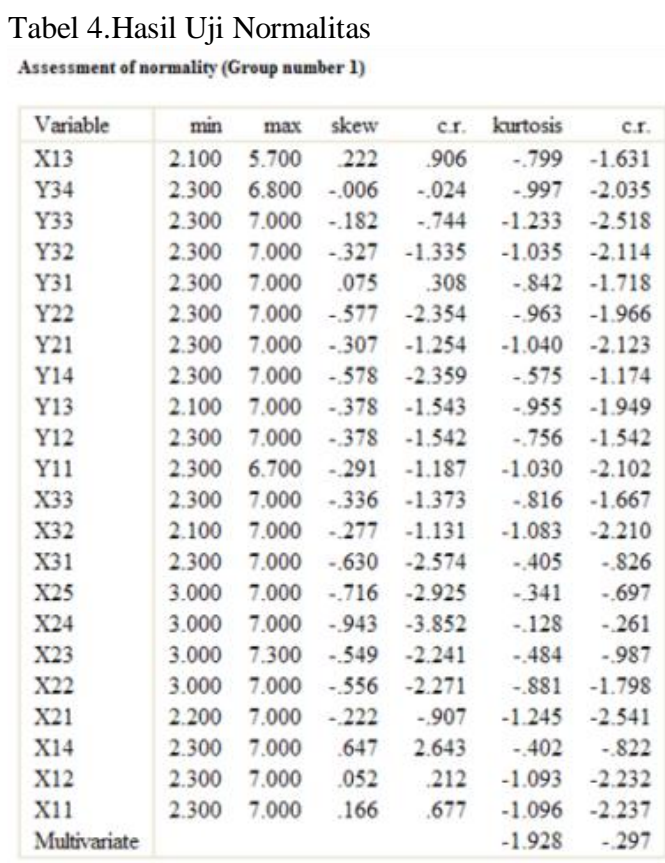

\subsection{Outliers}

Pada table mahalanobis distance yang dapat dilihat pada mahalanobis $d$-squared bahwa tidak terdapat outlier.

\subsection{Singularitas}

Uji asumsi multikolinearitas/singularitas di lakukan dengan mendeteksi nilai determinan matriks kovarians sample. Pada table sample covariances di table 3 dapat di lihat nilai determinan of sample covariances matrix $=.000$. Angka tersebut bukan berarti determinan 0, akan tetapi ada nilainya sehingga dapat di simpulkan tidak ada masalah 
multikolinearitas dan singularitas pada data yang di analisis.

Tabel 5. Hasil Uji Singularitas

\begin{tabular}{|c|c|c|c|c|c|}
\hline SQ & IQ & $\mathrm{SrQ}$ & $\mathbf{U}$ & US & LQ \\
\hline 0.000 & 0.000 & 0.000 & 0.000 & 0.000 & 0.000 \\
\hline $\mathrm{x} 13$ & X14 & $\mathrm{x} 12$ & x11 & & \\
\hline 4.682 & 1.767 & 1.201 & 1.000 & & \\
\hline $\mathrm{X} 25$ & X24 & $\mathrm{X}_{23}$ & X22 & X21 & \\
\hline 3.373 & 4.903 & 5.229 & 4.185 & 1.000 & \\
\hline X33 & X32 & X31 & & & \\
\hline 1.463 & 2.869 & 1.000 & & & \\
\hline Y14 & Y13 & Y12 & Y11 & & \\
\hline 0.500 & 4.828 & 1.405 & 3.162 & & \\
\hline Y22 & Y21 & & & & \\
\hline 0.500 & 0.500 & & & & \\
\hline Y34 & Y33 & Y32 & Y31 & & \\
\hline 0.25 & 6.05 & 4.163 & 1.000 & & \\
\hline
\end{tabular}

\subsection{Pengujian Validitas}

Pengujian terhadap validitas variabel laten dilakukan dengan melihat nilai Signifikansi (Sig) yang diperoleh tiap variabel indikator kemudian dibandingkan dengan nilai $\mathrm{P}(0,05)$. Jika Sig $\leq 0.05$ maka Tolak $\mathrm{H}_{0}$, artinya variabel indikator tersebut merupakan konstruktor yang valid bagi variabel laten tertentu [Widodo 2007,59].

\subsection{Pengujian Reliability}

Tabel 6. Uji Reliabilitas Gabungan

\begin{tabular}{|c|c|c|}
\hline KONSTRUK & $\begin{array}{c}\text { CONSTRUCT } \\
\text { RELIABILITY }\end{array}$ & $\begin{array}{c}\text { VARIANCE } \\
\text { EXTRACTED }\end{array}$ \\
\hline SrQ & 0.830 & 0.764 \\
\hline IQ & 0.851 & 0.563 \\
\hline SQ & 0.583 & 0.661 \\
\hline U & 0.861 & 0.647 \\
\hline US & 0.952 & 0.908 \\
\hline LQ & 0.701 & 0.626 \\
\hline
\end{tabular}

Pada tabel 6 terlihat semua konstruk variabel laten yaitu: SrQ, IQ, U, US, dan LQ ternyata memenuhi syarat cutt-of value untuk construct reability minimal 0,7 semuanya dan ternyata tidak memenuhi batas nilai variance extracted $<0,5$. Dengan demikian dapat dikatakan bahwa masingmasing variabel tidak memiliki reabilitas yang baik.

Hasil penggabungan setelah dilakukan analisis menggunakan uji Confirmatory
Factor Analysis (CFA) masih saja tidak bisa menghasilkan output antara hubungan variabel dengan indikator sehingga tidak dapat diukur seberapa fit dan valid dari data yang ada. Model yang ada tidak dapat digunakan sehingga harus menggunakan analisis menggunakan path analysis.

\subsection{Model Jalur (Path Analysis)}

Setelah dilakukan modifikasi model dengan analisis jalur, didapatkan model penelitian seperti yang tertera pada gambar:

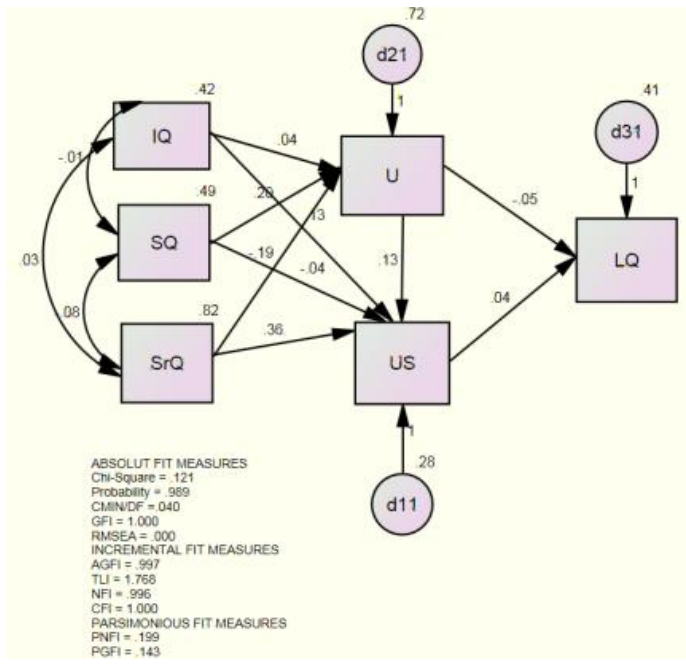

Gambar 4. Hasil Model Path Analysis

\subsection{Interpretasi Model}

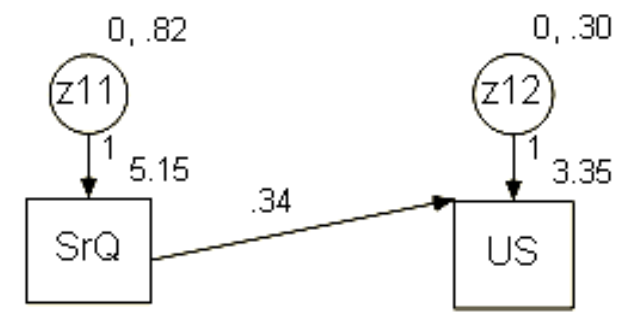

Gambar 5. Interpretasi Model Akhir

Model akhir yang didapatkan pada penelitian ini adalah gabungan / modifikasi dari model DeLone and McLean [DeLone 2003] yang sesuai dengan penelitian dan fenomena bahwa variabel Information Quality $(I Q)$ dan System Quality (SQ) tidak berpengaruh terhadap variabel Use $(U)$, User Satisfaction (US), dan juga tidak terlihatnya adanya signifikansi pada Learning Quality $(L Q)$.

Berdasarkan hasil penelitian dan fenomena yang ada di Binus Center imple- 
mentasi SI/TI yang digunakan tidak merasakan manfaatnya dan pengaruh terhadap kualitas pembelajaran yang ada didalam Binus Center. Ada pengaruh pengguna dan kepuasan pengguna dalam menggunakannya. Berdasarkan fenomena ini maka dapat dijelaskan bahwa implementasi SI/TI yang digunakan tidak efektif atau gagal karena tidak ada pengaruh dari SI/TI yang sudah diimplementasikan, terlihat dari data-data yang didapat melalui uji reliabilitas gabungan dapat dikatakan bahwa ang ada cukup valid namun tidak dibarengi dengan data ykualitas-kualitas yang digunakan untuk mengukur efektifitas implementasi SI/TI yang baik dan menunjang kualitas pembelajaran serta jarangnya perbaikan, jarang update informasi didalam sistem system informasi yang ada saat ini, dan yang paling terpenting adalah kurangnya sosialisai penggunaan sistem informasi yang ada saat ini, maka akan ditinggalkan oleh pengguna yang pada akhirnya berdampak pada perilaku individu. Dalam hal ini kebanyakan responden yang tidak menggunakan system informasi karena memang Sistem Informasi karena memang bukan dibuat untuk penunjang kualitas pembelajaran di Binus Center. Pada penelitian ditemukan bahwa system informasi yang ada hanya untuk menampilkan informasi mengenai penilaian dan juga banyak responden yang tidak mengetahui kegunaan dari system informasi yang ada sehingga banyak responden yang tidak menggunakan system informasi yang ada saat ini, kalau dalam implementasi TI membantu dalam peningkatan kualitas pembelajaran yang ada saat ini karena mulai dari infrastruktur dan peralatan TI yang digunakan sangat menunjang kegiatan pembelajaran di Binus Center.

Variabel (IQ) dan (SQ) penggunaan SI/TI di Training Center tidak mempengaruhi terhadap variabel (S), (US), dan (LQ) artinya semakin jarang implementasi SI/TI di Binus Center di gunakan maka akan semakin berpengaruh terhadap kualitas pembelajaran dapat dikatakan bahwa faktor utama implementasi SI/TI tidak berpengaruh terhadap kualitas pembelajaran adalah banyak responden tidak mengetahui adanya sistem informasi yang bisa digunakan dan juga terlebih lagi tidak ada sosialisasi penggunaan system informasi kepada para peserta dan instruktur. Didalam penelitian yang sedang dilakukan saat ini yang paling kuat pengaruhnya adalah antara Service Qaulity terhadap User Satisfaction berdasarkan hasil uji variabel. Dalam penerapan SI/TI pada Binus Center masih ada pengajar yang tidak dapat menggunakan SI/TI secara maksimal terlebih lagi bagi pengajar yang baru. IQ tidak berpengaruh terhadap $\mathrm{U}$ karena nilai yang didapat dari hasil penelitian adalah 0.032. SQ tidak berpengaruh terhadap U karena nilai yang didapat dari hasil penelitian adalah 0.157 . SrQ tidak berpengaruh terhadap $U$ karena nilai yang didapat dari hasil penelitian adalah

0.191 . IQ tidak berpengaruh terhadap US karena nilai yang didapat dari hasil penelitian adalah 0.032. SQ tidak berpengaruh terhadap US karena nilai yang didapat dari hasil penelitian adalah -0.041. U tidak berpengaruh terhadap US karena nilai yang didapat dari hasil penelitian adalah 0.178. U tidak berpengaruh terhadap LQ karena nilai yang didapat dari hasil penelitian adalah -0.069 . US tidak berpengaruh terhadap LQ karena nilai yang didapat dari hasil penelitian adalah 0.044 .

Learning Quality (LQ) tidak dipengaruhi oleh variabel Use $(U)$ dan User Satisfaction (US). Perilaku yang tidak positif dalam menggunakan penerapan SI/TI yang ada muncul karena tidak adanya kemanfaatan yang dirasakan oleh pengguna dalam menggunakan pererapan SI/TI dalam menunjang pembelajaran yang ada di Training Center.

\subsection{Implikasi Penelitian}

\section{a. Aspek Sistem}

Dengan adanya penilitian mengenai kualitas pembelajaran di Binus Center sehingga bisa dapat mengetahui juga bagaimana penerapan SI/TI yang ada dapat meunjang atau tidak dan ternyata hasilnya adalah tidak adanya hubungan penerapan SI/TI dengan kualitas pembelajaran. Dengan hasil yang tidak efektif maka ada hal yang di terapakan SI/TI dari segi sistem dan teknologi informasi harus dikembangkan terus menerus untuk kemanfaatan menunjang kualitas pembelajaran di training center. Penggunaan software Sistem Infor- 
masi dari segi sistemnya harus dikembangkan terus menerus untuk kemanfaatannya misalnya menampilkan informasi mengenai materi dan juga informasi terbaru yang berhubungan dengan kualitas pembelajaran yang ada di Training Center.

\section{b. Aspek Manajerial}

Dalam penelitian ini mendapatkan hasil yaitu tidak adanya sosialisasi yang baik kepada para pengguna sehingga adahal yang perlu dilakukan seperti Penggunaan software Sistem Informasi harus didukung penuh oleh pihak manajemen dan diberikan fasilitas pendukung untuk peningkatan kualitas pembelajaran. Adanya sosialisasi yang diberikan dari pihak manajemen untuk penggunaan SI/TI yang sudah diterapkan agar dapat maksimal untuk penggunaannya. Implementasi SI/TI yang diterapkan menjadi kebutuhan peserta, instruktur, dan juga staff. Perencanaan untuk memperbaiki system informasi yang sudah ada agar dapat digunakan peserta, instruktur, dan staff akademik dalam menunjang peningkatan kualitas pembelajaran seperti e-learning. Bagian pengolah SI/TI harus mempunyai rencana pengembangan dan juga perbaikan secara berkala.

\section{c. Penelitian Lanjutan}

Hasil penelitian ini juga dapat digunakan sebagai bahan referensi untuk penelitian selanjutnya, seperti pengukuran kualitas pembelajaran di Training Center lainnya. Dengan penelitian ini ada hal yang peneliti sarankan yaitu perlu adanya pengembangan Sistem Informasi yang dapat mendukung kualitas pembelajaran dengan pembuatan suatu aplikasi yang dapat digunakan untuk menunjang tingkat kualitas pembelajaran, perlu adanya pengintegrasian system antara sisfo yang ada dengan system yang dapat menunjang kualitas pembelajaran, uji efektifitas SI/TI yang sudah diterapkan menggunakan Model DeLone and McLean dikembangkan pada Training Center. Pada penelitian selanjutnya untuk kuesioner sebaiknya dikelompokan masingmasing, karena responden penerimaan penerapan SI/TI untuk peserta, instruktur, dan staff berbeda. Lakukan uji kelayakan penerapan SI/TI dengan DeLone and McLean secara berkala agar mengetahui perkembangan kualitas pembelajaran yang ada dan juga perkembangan penerapan SI/TI yang sudah diimplementasikan. Disarankan menggunakan aplikasi yang dapat menilai seberapa besarnya pengaruh penerapan SI/TI terhadap kualitas pembelajaran di Training Center. Factor contributing user acceptance (Independent variabel) pada model DeLone and McLean terdiri dari Information Quality (IQ), System Quality (SQ) mendapatkan respon yang kurang baik sementara nilai User Satisfaction cukup baik, harusnya kualitas informasi yang baik akan mendapatkan respon yang baik sehingga akan berdampak pada individu merasa cukup puas dalam penggunaan SI/TI yang sudah diterapkan.

\section{PENUTUP}

\subsection{Kesimpulan}

Berdasarkan hasil penelitian dan interpretasi, maka dapat ditarik kesimpulan sebagai berikut:

1. Berdasarkan teori [DeLone and McLean 2003] bahwa untuk menilai efektifitas suatu penerapan system informasi manajemen maka harus adanya signifikansi antara variabel-variabel Kualitas Sistem, Kualitas Inforamasi, dan kualitas layanan dengan penggunaan, Kepuasan Pengguna dan Manfaat. Karena tidak adanya hubungan yang signifikan dari variabel tersebut maka penerapan SI/TI yang ada di Binus Center dikatakan tidak efektif dan juga tidak mempunyai pengaruh terhadap kualitas pembelajaran;

2. Faktor-faktor yang berpengaruh dalam penelitian adalah Service Quality terhadap User Satisfaction tetapi dari faktor-faktor yang saling mempengaruhi tidak ada yang dapat mempengaruhi Learning Quality di Binus Center;

3. Bentuk model yang dapat menjelaskan hubungan kausal antar variabel dan indicator yang diacu untuk menilai tingkat keberhasilan penerapan SI/TI di Binus Center dalam meningkatkan kualitas pembelajaran bahwa kualitas system tidak memiliki pengaruh terhadap pengguna dan kepuasan pengguna. Kualitas informasi tidak memiliki pengaruh terhadap penggunaan dan 
kepuasan pengguna. Kualitas layanan mempunyai pengaruh terhadap kepuasan pengguna. Penggunaan dan kepuasan pengguna tidak dapat mempengaruhi kualitas pembelajaran yang ada. Pengguna mempunyai pengaruh terhadap dampak. Dari hasil penelitian tidak ditemukannya hubungan kausal antara variabel dan indicator untuk mengukur tingkat kualitas pembelajaran; dan

4. Karena tidak adanya hubungan yang kausal antar dimensi yang diacu maka tingkat penerapan SI/TI di Binus Center bisa dikatakan tidak efektif sehingga tidak dapat mempengaruhi kualitas pembelajaran.

\subsection{Saran}

Hasil penelitian membuktikan bahwa terjadi hubungan dan pengaruh positif secara signifikan antar variabel Model Sukses SI DeLone and McLean pada penerapan SI/TI pada Binus Center. Dengan hasil penelitian ini:

1. Binus Center senantiasa meningkatkan kualitas system dan informasi penerapan SI/TI dengan melakukan pemeliharaan system secara rutin, mempercepat waktu respon system apabila mengalami kerusakann, meningkatkan kualitas isi dan bentuk informasi serta waktu pemenuhan kebutuhan informasi secara cepat. Sehingga, para pengguna SI/TI yang ada di Binus Center dapat menggunakan system dan informasi secara optimal, tepat dan akurat dalam aktivitasnya;

2. Factor contributing user acceptance (independent variabel) pada model DeLone and McLean terdiri dari Information Quality dan System Quality pada penelitian mendapatkan nilai respon yang kurang baik sementara nilai User Satisfaction cukup baik karena User Satisfaction dipengaruhi oleh Service Quality, biasanya Kualitas Informasi akan baik sehingga akan berdampak pada individu yang akan merasa puas dan dengan adanya kepuasan pengguna juga bisa berdampak pada peningkatan kualitas pembelajaran;
3. Binus Center sebaiknya mengadakan sosialisasi tentang penggunaan Sistem Informasi yang sudah diterapkan selama ini dan terlebih lagi harus ada penambahan menu yang berisikan informasi mengenai pembelajaran agar dapat menunjang kegiatan pembelajaran. Dengan demikian akan meningkatkan kualitas pembelajaran;

4. Dalam memenuhi visi dan misi Binus Center, Sistem Informasi dan Teknologi Informasi yang diterapkan di Binus Center memerlukan SI/TI yang sesuai dengan perkembangan teknologi saat ini. Perangkat keras dan perangkat lunak harus disesuaikan dengan kebutuhan pengguna dan juga materi yang ada, dengan demikian diharapkan pada akhirnya SI/TI yang diterapkan dapat membantu meningkatkan kualitas pembelajaran yang ada di dalam Binus Center; dan

5. Arsitektur keamanan teknologi informasi yang perlu dimiliki, yaitu kumpulan sumber daya yang tersentralisasi (centralized resource), pengelolaan identitas (identity management), sistem otorisasi (authorization system), access control, pengelolaan kebijakan (policy management), sistem pemantau (monitoring system), security operation, intranet yang aman (secure intranet) LAN), dan Internet yang aman (Secure Internet).

\section{DAFTAR PUSTAKA}

[Akib 2005] Faisal Akib, 2005, "Definisi Teknologi Informasi”, http://teknikinformatika.com/teknologi-informasi/ (diakses 21 Januari 2011).

[Arry 2009] Arry, 2009, "Standarisasi Jaringan Outled Binus Center", Jakarta: Binus Center.

[DeLone \& McLean 2003] William H. Delone, Ephraim R. McLean, 2003, The Delone and McLean of Information System Success: A Ten-Year Update, USA. 
[Gundar 2005] Gundar, 2005, "Sistem Informasi", http:// agungsr.staff.gunadarma.ac.id/Downloa ds/files/3412/Konsep+SI.pdf (diakses 21 Januari 2011)

[Iivari 2002] Livari, Juhani, 2002, An Empirical Test of the DeLone-McLean Model of Information System Success.

[Kasidi 2000] Ravik Karsidi, 2000, Penerapan Teknologi Untuk Peningkatan Mutu Pendidikan, Makalah, Surakarta: Universitas Sebelas Maret.

[Levin 2005] Levenie, David M, 2005, Even You Can Learn Statistics, Prentice Hall.

[Mira 2010] Begona Perez, Mira, 2010,Validity Of Delone and Mclean's Model Of Information Systems at The Web Site Level of Analysis, Amerika Serikat.

[Mustafa 2000] Hasan Mustafa, 2000, Hasil Sampling,http:// forum.upi.edu/v3/index.php?topic $=162$ 80.0 (diakases 21 Januari 2011)

[Radzul 2007] Dody Radityo, Zulaikha, 2007, Pengujian Model DeLone and McLean Dalam Pengembangan Sistem Informasi Manajemen (Kajian Sebuah Kasus), Simposium Nasional Akuntansi, Makasar.
[Schaupp 2009] Ludwig Christian Schaupp, France Belanger, Weiguo Fan,2009, Examining The Success of Website Beyond E-Commerce: An Extension Of The Is Success Model, Virginia.

[Tom Cutchall, 1999] (http://www.arches.uga.edu/ cutshall/to mitdef.html) diakses 1 Januari 2011

[Valle et al, 2009] Antonio Valle, Jose C. Nunez, Ramon G. Cabanach, Julio A. Gonzalez-Pienda, Susana Rodriguez, Pedro Rosario, Maria A. MunozCadavid, Rebeca Cerezo, 2009, Academic Goals and Learning Quality in Higher Education Students, The Spanish Journal of Psychology, Vol. 12, No. 1, 96-105, Spanish.

[Wahid 2005] Fathul Wahid, 2005, Peran Teknologi Informasi Dalam Modernisasi Pendidikan Bangsa, Yogyakarta.

[Widodo 2007] Widodo, Prabowo Pudjo, 2007, Seri Structural Equation Modelling, Universitas Budi Luhur. 